\title{
THE INFLUENCE OF A CANNULA IN THE RABBIT OVIDUCT
}

\author{
I. OVIDUCT FLUID LIPIDS AND PROTEINS
}

\author{
M. H. SLOAN AND A. D. JOHNSON* \\ Animal Science Department, Livestock-Poultry Building, \\ University of Georgia, Athens, Georgia 30602, U.S.A.
}

(Received 8th October 1973)

Rabbit oviduct secretions have been analysed following ligation (David, Brackett, Garcia \& Mastroianni, 1969), flushing (Olds \& VanDemark, 1957) or cannulation of the genital tract (Holmdahl \& Mastroianni, 1965). Data obtained from ligation have been questioned because of possible occlusion of the blood supply and histological damage. Flushing has the limitation of one sample per animal, so that any change with treatment or stage cannot be verified. This study was designed to determine if the secretions of a cannulated oviduct differ from those of the intact oviduct of the same individual.

A $6 \mathrm{~cm}$-long silastic cannula ( $1.57 \mathrm{~mm}$ i.d., $2.4 \mathrm{~mm}$ o.d.) was inserted through a mid-ventral incision into the fimbriated end of one oviduct of each of twenty virgin does. The cannula was surrounded by a velour cuff $2 \mathrm{~mm}$ wide placed $1 \mathrm{~cm}$ from the tip. About three stitches were taken into the velour through the oviducal wall. Major vessels were avoided to prevent disturbance of the vasculature. The intact contralateral oviduct served as the control for each animal. The cannula was left open so that fluid could flow and remained in the abdominal cavity for approximately 2 weeks. To ensure that all does were in the same oestrous state, the oviduct was flushed only after the doe accepted the male.

Immediately after mating, blood was obtained by cardiac puncture, and the doe was killed with an overdose of sodium pentobarbitone. Collection of oviducal secretions was accomplished by flushing the oviducts with $3 \mathrm{ml}$ physiological saline using a 22-gauge needle inserted into the lumen just anterior to the uterotubal junction. The control oviduct was temporarily cannulated with a $6-\mathrm{cm}$ silastic cannula for the flushing procedure. The period of time from collection to freezing of the samples was less than $15 \mathrm{~min}$ in all cases.

Samples used for protein analysis were freeze-dried and resuspended in $0.5 \mathrm{ml}$ distilled water. Total protein was determined by the biuret procedure (Henry, Sobel \& Berkman, 1957). Photometric determination was made utilizing the Spectronic 20 (Bausch \& Lomb) with bovine serum albumin (BSA) serving as the standard. Protein type patterns were analysed by polyacrylamide disc gel electrophoresis (Davis, 1964). At the termination of electrophoresis, gels were stained for protein with Amido Black (1.0\%). All electro-

\footnotetext{
* Correspondence to Dr A. D. Johnson.
} 
phoretic runs included rabbit serum at $1 / 10$ the oviducal fluid volume for reference purposes. Relative values for comparison of protein concentrations were obtained from densitometric tracings (Gelscan Automatic Recording and Integrating Scanner).

Lipids were separated by thin-layer chromatography (Freeman \& West, 1966) and quantifications were by the Amenta (1964) method. Statistical differences were evaluated using Student's $t$ test (Steel \& Torrie, 1960).

Text-figure 1 shows the mean values observed $(\mathrm{mg} \pm$ S.E./oviduct for total protein concentration). The protein concentration in the cannulated oviducts $(0.73 \pm 0.08 \mathrm{mg} /$ oviduct $)$ was slightly, but not significantly, higher than in the control oviducts $(0 \cdot 62 \pm 0 \cdot 05 \mathrm{mg} /$ oviduct $)$.

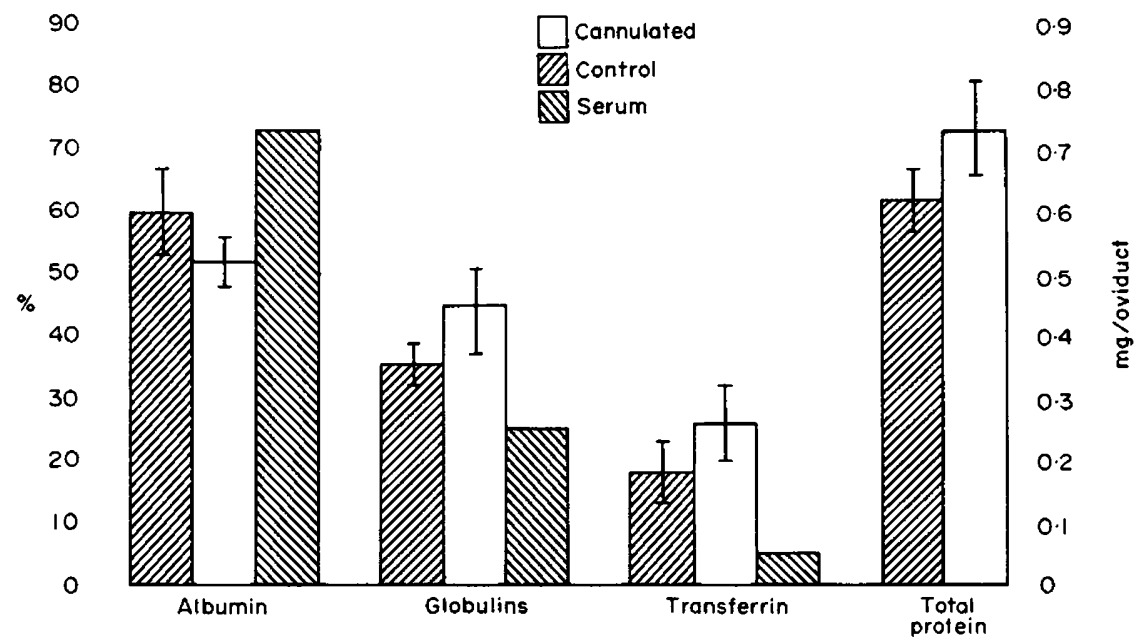

TexT-Fig. 1. The \% of albumin, globulin and transferrin in the fluid of cannulated and control rabbit oviducts with BSA as a reference. The total protein in mg per oviduct (means \pm S.E.) is also shown.

The major protein fraction appearing in the secretions of the cannulated and control oviducts of the oestrous, mated rabbit corresponded (Text-fig. 1) to serum albumin. Densitometric tracings revealed that this band comprised approximately $52 \pm 4 \%$ and $60 \pm 8 \%$ of all proteins measured in oviducal fluid, respectively. This difference was not significant. Shapiro, Jentsch \& Yard (1971), Feigelson \& Kay (1972) and Foley, Engle, Plotka, Roberts \& Johnson (1972) using rabbit oviducal fluid, and Moghissi (1970) using human oviducal fluid, have shown that albumin is the principal protein of oviducal fluid. Total globulins (Text-fig. 1) were slightly, but not significantly, higher $(46 \pm 7 \%)$ for cannulated than for control oviducts $(35 \pm 4 \%)$. The band corresponding to transferrin of rabbit serum was essentially constant for both cannulated and control secretions $(26 \pm 6 \%$ and $18 \pm 5 \%$, respectively).

The protein patterns of the secretions collected by flushing from the mated doe agree with those of the secretions of non-mated (Feigelson \& Kay, 1972) and mated does (Foley et al., 1972) collected by cannulation. Due to the dilution of the fluid collected by flushing, minor bands were not readily discernible at 


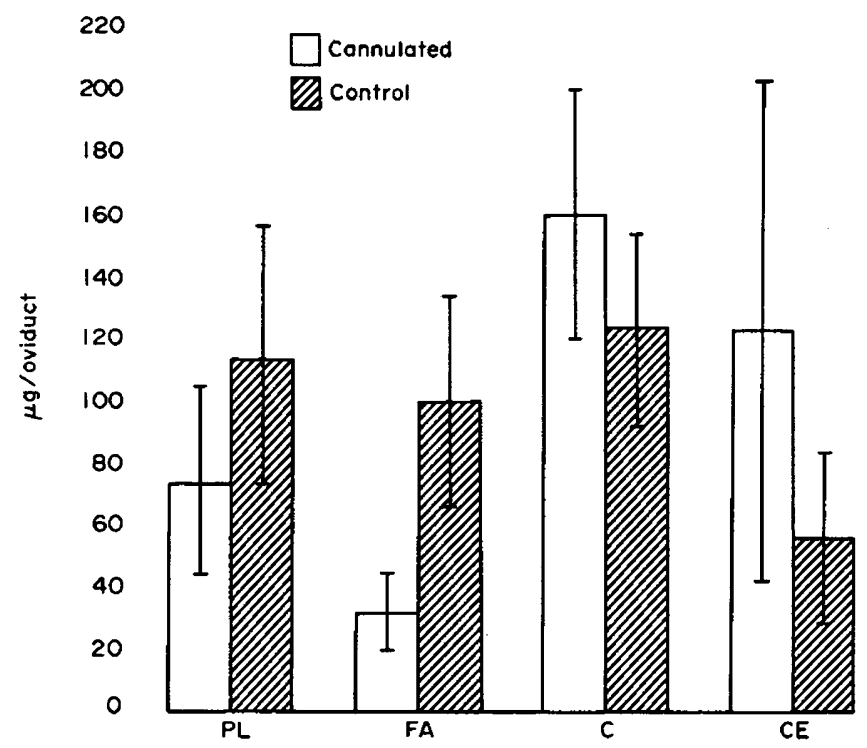

TexT-Fig. 2. The concentrations in $\mu$ g/oviduct of phospholipids (PL), fatty acids (FA), cholesterol (C) and cholesterol esters (CE) in the fluids of the cannulated and control oviducts from the same rabbits.

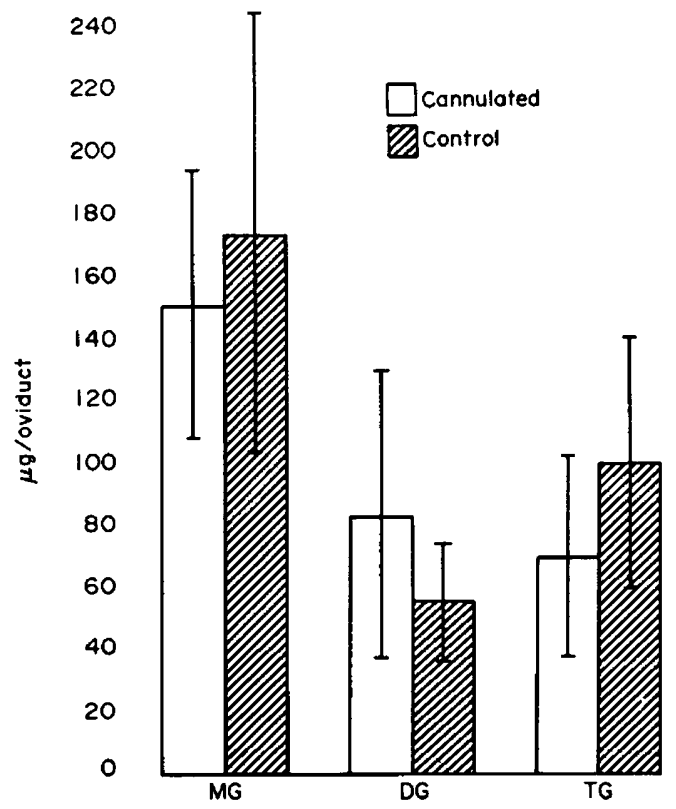

TExT-Fic. 3. The concentrations in $\mu$ g/oviduct of monoglycerides (MG), diglycerides (DG) and triglycerides (TG) in the fluids of the cannulated and control oviducts from the same individuals. 
the concentration used in this study. Vague bands $(1.0 \%)$ were seen in the preand post-albumin regions of the samples with no differences apparent between fluids of the cannulated and control oviducts. Feigelson \& Kay (1972) reported a carbohydrate pre-albumin band, an oestrogen-dependent post-albumin band and two bands in the gamma region which were not apparent in rabbit serum.

The results observed by disc gel electrophoresis of protein types in this experiment show that there is essentially no difference in the secretions of the cannulated and non-cannulated oviduct of the same individual.

Lipids have been identified in rabbit oviducal tissue (Gupta, Karkun \& Kar, 1967). Examination of the oviducal fluid from uterine horns containing an IUD (silk suture) led Kar, Kamboj, Chowdhury \& Chowdhury (1965) to suggest that more lipids accumulated in the fluid of the treated oviduct $(265 \mathrm{mg} \%$ ) than in the control oviduct $(252 \mathrm{mg} \%)$. Phospholipids of oviduct secretions have been reported which range from trace amounts to $80 \mathrm{mg} / \mathrm{ml}$ (Bishop, 1957) in oestrous rabbits.

In this study, the presence of a cannula in the fimbriated end of the oviduct did not significantly alter the concentration of lipids, as revealed by thin-layer chromatography and quantification. Text-figures 2 and 3 show the mean values \pm S.E. of the lipid classes found for cannulated and control oviducts. Although there was variation between individual lipid classes and the total lipid concentration was higher in the controls, no significant difference was found between lipid types among individuals.

Considerable work with lipid in other tissues (e.g. in the testis; Johnson, 1970) suggests a marked rise in the total lipids and particularly in certain lipid classes when any damage occurs to the tissue. If this holds true for the oviduct tissue and its effluent, it is apparent that the cannula does not damage the oviduct.

It is evident from this work that the presence of a cannula does not upset lipid and protein balances in the oviduct. Since little biochemical change occurs with cannulation, the question remains, can embryos develop within this cannulated oviduct?

\section{REFERENGES}

AmENTA, J. S. (1964) A rapid chemical method for quantification of lipids by thin-layer chromatography. F. Lipid Res. 4, 270.

Bishop, D. W. (1957) Metabolic conditions within the oviduct of the rabbit. Int. F. Fert. 2, 11.

David, A., Brackett, B. G., Garcia, G. R. \& Mastroianni, L., JR (1969) Gomposition of rabbit oviduct fluid in ligated segments of the Fallopian tube. 7. Reprod. Fert. 19, 285.

DAvis, B. J. (1964) Disc electrophoresis. II. Method and application to human serum proteins. Ann. N.Y. Acad. Sci. 121, 404 .

Feigelson, M. \& Kay, E. (1972) Protein patterns of rabbit oviducal fluid. Biol. Reprod. 6, 244.

Foley, G. W., Engle, G. G., Plotka, E. D., Roberts, R. C. \& Johnson, A. D. (1972) Influence of early pregnancy on the oviduct fluids of the rabbit. Am. F. vet. Res. 33, 2059.

Freeman, C. P. \& West, D. (1966) Complete separation of lipid classes on a single thin-layer plate 7. Lipid Res. 7, 324.

Gupta, D. N., Karkun, J. N. \& Kar, A. B. (1967) Biochemical composition of different portions of rabbit fallopian tube. Indian $\mathcal{F}$ nl exp. Biol. 5, 124.

Henry, R. J., Sobel, G. \& Berkman, S. (1957) Interference with biuret method for serum protein. Use of Benedict's qualitative glucose reagent as a biuret free agent. Analyt. Chem. 29, 1491 .

Holmdahl, T. H. \& Mastroianni, L., JR (1965) Continuous collection of rabbit oviduct secretions at low temperature. Fert. Steril. 16, 587. 
Johnson, A. D. (1970) Testicular lipids. In The Testis, Vol. II, pp. 194-258. Eds. A. D. Johnson, W. R. Gomes and N. L. VanDemark. Academic Press, New York.

Kar, A. B., KamboJ, V. P., Ghowdhury, S. R. \& Ghowdhury, A. R. (1965) Effects of a contraceptive suture on biochemical composition of the rabbit fallopian tube fluid. Indian $7 n l$ exp. Biol. 3, 268.

Mogrissi, K. S. (1970) Human fallopian tube fluid. I. Protein composition. Fert. Steril. 21, 821.

Olds, D. \& VanDemark, N. L. (1957) Composition of luminal fluids in bovine female genitalia. Fert. Steril. 8, 345.

Shapiro, S. S., Jentsch, J. P. \& YARD, A. S. (1971) Protein composition of rabbit oviducal fluid. 7. Reprod. Fert. 24, 403.

Steel, R. G. D. \& Torrie, J. H. (1960) Principles and Procedures of Statistics. McGraw-Hill, New York. 